\title{
Letter to the Editor: Overexpression of Myostatin2 in zebrafish reduces the expression of dystrophin associated protein complex (DAPC) which leads to muscle dystrophy
}

\author{
Buel D. Rodgers \\ Department of Animal Sciences, School of Molecular Biosciences, Washington State University, \\ Pullman, USA e-mail: danrodgers@wsu.edu
}

\begin{abstract}
I recently read "Overexpression of Myostatin2 in zebrafish reduces the expression of dystrophin associated protein complex (DAPC) which leads to muscle dystrophy" (Amali et al. Epub, May 6) with great interest, but also with some concern. The authors claim to have cloned for the first time a second myostatin homolog in zebrafish and partially characterized its function. However, the cDNA and genomic clones for this gene were reported in 2005 by two different research groups, including our own [1,2], although these studies were not referenced by Amali et al. These sequences have also been publicly available since this time and are accessible from GenBank. In fact, all of the data presented in the first three figures of Amali et al. were formerly presented in part or, in some instances, in much greater detail. Readers should be made aware of this oversight for two very important reasons. Firstly, the gene nomenclature used by Amali et al. is incorrect as the entire subfamily's nomenclature was revised last year [3]. Many of the fish gene names did not match the previously determined phylogenies $[2,4,5]$ and as such, the revised nomenclature was accepted by the Mouse Genomic Nomenclature Committee and the Human Genome Organization (HUGO) Gene Nomenclature Committee, which subsequently revised their databases. This change was also propagated to other public databases including those managed by the National Center for Biotechnology Information (NCBI) and Ensemble. The old and misleading nomenclature that misidentifies myostatin (MSTN)-1 with MSTN-2 (and vice versa) was used by Amali et al., further confuses the field and needs to be corrected. In fact, the phylogenetic analysis by Amali et al. includes several genes that are "misplaced" in the wrong clade, although this was not recognized by the authors. Secondly, and probably most importantly, appropriate credit and future references should be directed to the young scientists whose career advancements depend upon the recognition of their hard work [1,2]. Amali et al. present some intriguing and novel data that are worthy of attention. However, identification of the second paralogous myostatin gene family as well as the characterization of the zebrafish clones was accomplished by Kerr et al. and Biga et al. in 2005 and not by Amali et al. in 2008.
\end{abstract}

\section{References}

1. Biga PR, Roberts SB, Iliev DB, McCauley LA, Moon JS, Collodi P, Goetz FW. The isolation, characterization, and expression of a novel GDF11 gene and a second myostatin form in zebrafish, Danio rerio. Comp Biochem Physiol B Biochem Mol Biol 2005;141:218-230. [PubMed: 15886039]

2. Kerr T, Roalson EH, Rodgers BD. Phylogenetic analysis of the myostatin gene sub-family and the differential expression of a novel member in zebrafish. Evol Dev 2005;7:390-400. [PubMed: 16174033]

(C) National Science Council Taipei 2008

Correspondence to: Buel D. Rodgers. 
3. Rodgers BD, Roalson EH, Weber GM, Roberts SB, Goetz FW. A proposed nomenclature consensus for the myostatin gene family. Am J Physiol Endocrinol Metab 2007;292:E371-E372. [PubMed: 17003236]

4. Ostbye TK, Wetten OF, Tooming-Klunderud A, Jakobsen KS, Yafe A, Etzioni S, Moen T, Andersen O. Myostatin (MSTN) gene duplications in Atlantic salmon (Salmo salar): evidence for different selective pressure on teleost MSTN-1 and -2. Gene 2007;403:159-169. [PubMed: 17890020]

5. Garikipati DK, Gahr SA, Roalson EH, Rodgers BD. Characterization of rainbow trout myostatin-2 genes (rtMSTN-2a and-2b): genomic organization, differential expression, and pseudogenization. Endocrinology 2007;148:2106-2115. [PubMed: 17289851] 